Article

\title{
From Peripheral to Integral? A Digital-Born Journalism Not for Profit in a Time of Crises
}

\author{
Alfred Hermida * and Mary Lynn Young \\ School of Journalism, University of British Columbia, Vancouver, V6T 1Z2, Canada; E-Mails: alfred.hermida@ubc.ca (A.H.), \\ marylynn.young@ubc.ca (M.L.Y.) \\ * Corresponding author
}

Submitted: 12 June 2019 | Accepted: 16 October 2019 | Published: 17 December 2019

\begin{abstract}
This article explores the role of peripheral actors in the production and circulation of journalism through the case study of a North American not-for-profit digital-born journalism organization, The Conversation Canada. Much of the research on peripheral actors has examined individual actors, focusing on questions of identity such as who is a journalist as opposed to emergent and complex institutions with multiple interventions in a time of field transition. Our study explores the role of what we term a 'complex peripheral actor,' a journalism actor that may operate across individual, organizational, and network levels, and is active across multiple domains of the journalistic process, including production, publication, and dissemination. This lens is relevant to the North American journalism landscape as digitalization has seen increasing interest in and growth of complex and contested peripheral actors, such as Google, Facebook, and Apple News. Results of this case study point to increasing recognition of The Conversation Canada as a legitimate journalism actor indicated by growing demand for its content from legacy journalism organizations experiencing increasing market pressures in Canada, in addition to demand from a growing number of peripheral journalism actors. We argue that complex peripheral actors are benefitting from changes occurring across the media landscape from economic decline to demand for free journalism content, as well as the proliferation of multiple journalisms.
\end{abstract}

\section{Keywords}

digital journalism; digital news; journalism; peripheral actors

\section{Issue}

This article is part of the issue "Peripheral Actors in Journalism: Agents of Change in Journalism Culture and Practice" edited by Avery E. Holton (University of Utah, USA), Valerie Belair-Gagnon (University of Minnesota-Twin Cities, USA), and Oscar Westlund (Oslo Metropolitan University, Norway / Volda University College, Norway / University of Gothenburg, Sweden).

(C) 2019 by the authors; licensee Cogitatio (Lisbon, Portugal). This article is licensed under a Creative Commons Attribution 4.0 International License (CC BY).

\section{Introduction}

This article explores the role of peripheral actors in the production and circulation of journalism through the case study of a North American not-for-profit, digitalborn journalism organization. A number of scholars have charted the changing and porous boundaries in journalism given the increasing number of actors afforded by digitalization (Bruns, 2018; Carlson, 2016; Hermida, 2016; Meraz \& Papacharissi, 2016). These actors range from technologists to non-human Al bots and novel pro- fessional identities. This study is focused on what we are calling a 'complex peripheral actor,' an emergent journalism organization that is peripheral on multiple levels, from who creates and produces its content to how it is distributed. Specifically, we follow The Conversation Canada and its first few years after launch to explore how it is taken up in a national media system undergoing economic transformation.

Much of the research on peripheral actors (Ahva, 2017; Eldridge, 2017; Holton \& Belair-Gagnon, 2018) has examined individual actors, focusing on questions 
of identity such as who is a journalist as opposed to emergent complex institutions with multiple interventions in a time of field transition. In this article, we analyze The Conversation Canada as a complex peripheral actor that has emerged in a digital journalism ecosystem (Bruns, 2018; Konieczna, 2018; Siles \& Boczkowski, 2012). In our definition, a complex peripheral actor is a journalism actor that may operate across individual, organizational, and network levels, and is active across multiple domains of the journalistic process, including production, publication, and dissemination. What distinguishes The Conversation Canada as a complex peripheral actor is that it is peripheral at three levels in the journalistic process - the production, publication, and dissemination of journalism.

It produces explanatory journalism written by academics, who have historically participated as sources and op-ed writers, and edited by journalists. The publication level relates to The Conversation Canada as a novel editorial actor funded largely by the higher education sector but at arm's length editorially that generates and shares this content free for reuse under Creative Commons. The dissemination level relates to the organizations that republish the articles, which represent a mix of core and peripheral actors in journalism from legacy journalism organizations to universities. The Conversation model provides for both on-site and off-site distribution with the aim of maximizing reach, given an increasingly fragmented and distribution media environment, where audiences stumble across news content on a variety of platforms, devices, and publications (Newman, Fletcher, Kalogeropoulos, Levy, \& Nielsen, 2017).

We approach this topic as co-founders, board members of The Conversation Canada, and as a result, participant observers and "reflective practitioners" (lacono, Brown, \& Holtham, 2009, p. 39). Methodologically, we contend this approach is an appropriate stance for two reasons. First, it supports an examination of fastchanging industries characterized by a largely implicit professional knowledge system such that "little is done to capture and retain the tacit knowledge of practitioners" in a systematic and contemporary manner (lacono et al., 2009, p. 44). Second, it supports the real-time sharing of the problems, their context, and resolution of professional journalism practice. Professional practice development in general has been described as a process with the "best professionals...able to make sense of these 'messes,' discern patterns, identify deviations from a norm, recognize phenomena and adjust their performance" (lacono et al., 2009, p. 42). The site is particularly relevant for this kind of intervention and methodological approach as not-for-profit journalism organizations are increasingly being considered a model and antidote to some of the economic challenges facing the news business. We also have unique and timely access to proprietary data (lacono et al., 2009). In order to mitigate bias, we have drawn from comparative journalism organizational data and external commentary on The
Conversation Canada in addition to internal contributor, audience, and republishing data. Our goal is to support knowledge generation in this emergent space. We have not and do not earn any money from our participation in The Conversation Canada.

Our study finds that, following an initial lukewarm reception to its launch from within the field of journalism, The Conversation Canada is gaining uptake from scholars and republishers despite no paid advertising and limited national knowledge of the brand. As of June 2019, after 24 months in operation, it had published 1,937 articles by 1,558 scholarly contributors, recorded 31 million page views on- and off-site, with articles appearing in 527 republishers globally. That this complex peripheral actor is integrating and growing is interesting for what it suggests about the openness of the field of journalism in commercial market decline. Surprisingly, we also find its content being taken up by a growing number of peripheral journalism actors with the largest and most prominent nonelite republisher, The Weather Network (Canada), which is not conventionally considered journalism along with programs such as The Daily Show, according to contemporary definitions (Zelizer, 2004).

Peripheral actors account for just under half (45\%) of the audience reached by the top 50 republishers, with two thirds of the audience outside of Canada. The figures suggest demand for a certain kind of recognizable free Canadian journalism content within the country and globally (DiMaggio \& Powell, 1983, p. 148). This evidence is paradoxical given Canada's highly concentrated commercial journalism sector (Winseck, 2018), which has been historically critiqued for its parochial approach to journalism (Gasher, 2007), as well as its reliance on news flows from the US (Davey, 1970; Kent, 1981), suggesting that the field in transition is changing access to and interest in peripheral journalism institutions.

\section{Peripheral Actors in Journalism}

The notion of peripheral actors is rooted in an understanding of journalism as an organizational field with boundaries that serve to delineate what is journalism and who is a journalist. As Grafström and Windell (2012, p. 66) suggest, "the social sphere of journalistic practice is permeated with a common meaning system that gives field constituents a shared perception of who news producers are, what constitutes news and how it is practiced." The internet and digitalization have impacted the relatively stable field of journalism of the 20th century, with the emergence of actors outside the field of journalism undertaking activities traditionally associated with the profession.

Journalists and news organizations have acknowledged and incorporated the input of mostly individual actors outside the profession, but by and large they have been kept at arm's length and cast as outside the core of journalism (Nielsen, 2012; Singer et al., 2011; Tandoc $\&$ Oh, 2017). Such an approach emerges in work on the 
professional status of online journalists (Singer, 2003), the occupational challenge from bloggers (Lowrey, 2006) and audience participation in news spaces (Singer et al., 2011), as well as the impact of technologies such as social media (Hermida, 2016) and web analytics (BelairGagnon \& Holton, 2018). The rise of these peripheral forces, in the words of Lewis (2012, p. 838), "strikes at the heart of a model that was built on an implicit bargain between journalists and the public-an assumption about how society should handle the collection, filtering, and distribution of news information."

Various terms have been used to describe individuals as peripheral actors and their impact on the field of journalism. In her work, Ahva (2017) uses the term 'in-betweeners' to refer to a range of citizens, such as activists, academics, and artists involved in journalism. She defines 'in-betweeners' as "citizens who are not professional journalists, yet play a greater role in the journalistic process than mere receivers; they are not the typical audiences, either" (Ahva, 2017, p. 142). In his 2017 book, Eldridge examines the nature of emerging digital actors in journalism, describing them as interlopers. For him, these interlopers embody "a pushback against an idea that 'journalism' rests solely with the traditional media field" (Eldridge, 2017, p. 184), further arguing that these "bedeviling actors...indicate for scholars and those invested in journalism a need to build a more nuanced and analytically coherent argument to explore these emerging actors when and how they emerge" (Eldridge, 2017, p. 15).

Building on past work, Holton and Belair-Gagnon (2018, p. 70) propose a typology of "journalistic strangers" to describe individuals engaged in journalism. There are explicit interlopers, for example bloggers, who "may not necessarily be welcomed or defined as journalists and work on the periphery of the profession while directly contributing content or products to the creation and distribution of news" (Holton \& Belair-Gagnon, 2018 , p. 73). There are also implicit interlopers, for example programmers, "whose alignments with journalism are less clear than explicit interlopers" (Holton \& BelairGagnon, 2018, p. 74) and do not necessarily contest journalistic authority. The third category are intralopers, for example in-house developers, who are "working from within news organizations without journalism-oriented titles, they may be trained in journalism or be well versed in the craft of the profession" (Holton \& Belair-Gagnon, 2018, p. 75).

By comparison, Baack (2018) identifies four groups of individual actors in his study of the interlocking practices of data journalists and civic technologists. For him, the interactions between core actors, the journalists, and those on the periphery, the civic technologists, run along "a shared continuum that oscillates between practices of facilitating and gatekeeping" (Baack, 2018, p. 688). What is particularly applicable here to The Conversation Canada is Baack's argument that facilitation and gatekeeping practices "mutually reinforce each other," and, as a result, make "journalism as a professional practice more permeable to outsiders and allowed actors outside the field of journalism to increasingly engage in practices traditionally attributed to journalism" (Baack, 2018, p. 689). The Conversation model of journalism fits on the spectrum between facilitation and gatekeeping as it publishes explanatory journalism written by academics and edited by journalists.

Academics have historically worked on the edges of journalism, contributing as sources, experts, and op-ed writers. In The Conversation model, researchers take on the role of the journalist and the traditional roles of pitching and writing a story. In the words of the co-founder of The Conversation model, Andrew Jaspan, “Why don't I just turn this university into a giant newsroom? Why don't I just get all these incredibly smart people within their various faculties to become journalists and write for the public?" (as cited in Rowe, 2017, p. 232). The model relies on what Rowe calls "a ready supply of donated academic labour" (Rowe, 2017, p. 232) as scholars are not paid for contributions. The paid employees are the journalists who make up the editorial team.

In The Conversation model, scholars suggest stories through an online pitch form and write 800- to 1,000word textual explanatory journalism articles that range from commentary to analysis to educational 'news you can use.' Prominent and popular examples include articles headlined "What is Neoliberalism?" These forms of explanatory journalism would be considered established forms of journalism that builds on their "symbolic efficacy, that is, authority conferred by being recognized, mandated by collective belief" (Bourdieu, 1984, p. 251) or as Donsbach (2010, p. 38) suggests that "the identity of journalism as a profession lives on the assumption 'I know it when I see it'."

The scholars work in partnership with professionally trained journalist-editors, who play a dual role. They act as gatekeepers in many decisions of what to publish and as facilitators to support academics in producing content in a journalistic style. The scholar as a peripheral actor is not only at the core of the journalism of The Conversation, but some degree of gatekeeping power. Researchers retain final sign-off on publication, a practice that would not have been seen as aligned with journalism in a pre-digital era and that could be seen as challenging the autonomy of the newsroom.

The emerging scholarship on peripheral actors provides a number of approaches that are useful in understanding how powerful the impulse is within journalism studies to narrowly define who are the authoritative journalism actors by using comparison techniques that frame newer players as 'strangers' and 'interlopers' such that while their role identities and contributions are acknowledged they are still located on the far and unwelcome edges of the field. It is also valuable in considering how far entanglements with peripheral actors, particularly at an individual level, tend either towards opening up or limiting the journalistic field (cf. Baack, 2018). 


\subsection{Impact of Peripheral Actors on the Field}

A number of studies of peripheral actors have explored the relationship of peripheral actors and the field. For example, studies have focused on the gatekeeping and framing effects of peripheral actors on journalism coverage and reporting of protest movements such as "Occupy Wall Street" (Bennett, Segerberg, \& Yang, 2018) and "Idlenomore" (Callison \& Hermida, 2015), finding an increasing role for peripheral actors as grassroots organizations and activists. Research on field transformation points to change through incremental processes or more abrupt breaks (Schneiberg, 2007). An example of incremental change comes in the study of the US radio industry by Leblebici, Salancik, Copay, and King (1991). They tracked how peripheral actors at the fringe of broadcasting slowly gained more prominence within the field, with the central actors taking on practices from the edges.

More contemporary research has examined the interaction between bloggers and the mainstream press in Sweden (Grafström \& Windell, 2012). The study found that bloggers did not challenge the dominance of the key actors, in this case Swedish national dailies. Rather, these peripheral actors served to strengthen existing structures, with limited power to affect mainstream journalistic practices. Grafström and Windell conclude that "even though novel actors are given access to and become members of the field, the structures of domination are not altered" (2012, p. 74). Similar research on the sub-field of data journalism surfaces the interplay between peripheral and central actors. In their study of data journalism in Canada, Hermida and Young (2019) suggested that data journalists, particularly in well-resourced newsrooms, are operating as institutional entrepreneurs through their contributions to important discussions about journalism method and pressing epistemological concerns for the field.

There is less work focused on peripheral actors that go beyond individuals. Some of this research explores the impact of technologies, such as the interplay between web analytics and journalism (Belair-Gagnon \& Holton, 2018). Work that is relevant to this study is the influence of funders, and funding models, of journalism as peripheral actors. Scott, Bunce, and Wright (2019) examined how foundation funding affected journalistic practices and editorial priorities, leading to journalists extending their role definition and undertaking an increasing range of activities such as administration and marketing, and a greater focus on thematic content. Another study of not-for-profits focused on data journalism operating in the civic tech space in Europe and Africa (Cheruiyot, Baack, \& Ferrer-Conill, 2019) found these organizations were promoting and sustaining established journalistic practices, especially in contexts where data journalism was nascent. Still further research is examining the role of not-for-profit journalism organizations and Indigenous journalists on the possibility of field re- pair, reform, and transformation (Benson, 2017; Callison \& Young, in press; Konieczna, 2018).

\section{Methods}

Our study is an early descriptive analysis of the uptake of a nascent complex peripheral actor in one national context. Theoretically, our study seeks to build on approaches that: 1 ) explore peripheral actors beyond the individual; and 2) examine the role of peripheral actors in the changing field of journalism. Specifically, our research questions are: 1) How does an emergent complex peripheral journalism actor gain uptake in a national media system?; and 2) How does the media ecology affect the actor's uptake as journalism?

We use a single national site, The Conversation Canada, as a case study to explore changes in a media ecology defined by the periphery-core metaphor. We defined peripheral journalism actors, similar to Holton and Belair-Gagnon (2018, p. 70), as "those who have not belonged to traditional journalism practice but have imported their qualities and work into it." The Conversation Canada is both an early stage national not-for-profit digital-born organization and part of the global network that includes seven national partners (Australia, Indonesia, France, Spain, UK, US, and South Africa). As one of the group's newest partners, The Conversation Canada soft-launched in English in June 2017 with more than $\$ 1.5 \mathrm{M}(\mathrm{Cdn})$ in funding. The Frenchlanguage version, La Conversation Canada, was launched in December 2018. For this study, we have focused on the English-language site given the more extensive amount of available data.

The study is based on a range of data sources related to publication. Publication data was obtained from The Conversation's proprietary analytics software. Data for on-site traffic is drawn from Google Analytics which provides details of page views, unique users, devices, and other factors. Republishing data comes from an invisible $1 \times 1$ tracking pixel posted on third-party sites which tracks the republishing site and the browser user-agent version, which is aimed at excluding traffic from bots. The tracking pixel does not collect user data. The researchers were granted access to data to the analytics software, which allows data to be selected according to readership, article, author, and republisher, and downloaded as an Excel spreadsheet. The data was collected for the period from the launch of The Conversation Canada on June 24, 2017, to April 30, 2019.

Overall, The Conversation network of sites reports an average monthly audience of 10.7 million users, and a reach of 38.2 million through Creative Commons republication. The Conversation Canada was averaging more than 1.4 million monthly page views monthly by April 2019, with a third of page views onsite and two-thirds from republishers. The data on republishers is recorded by The Conversation's tracking software. Republishers are asked to include a tracking pixel when they use 
a story, which must be published in its entirety and unedited from the original. The only aspect that can be changed is the headline. The tracking pixel provides data to The Conversation on the republisher and page views for each article.

Page views are one measure of reach widely used in the media industry (Groves \& Brown, 2011; Usher, 2012), though we acknowledge that they have limitations. Figures may be skewed by a small number of users viewing a high number of pages (Krall, 2009). There are concerns over automated bot traffic to a site, with an industry report suggesting that bots accounted for 37.9\% of internet traffic in 2018 (Distil Networks, 2019). Moreover, we acknowledge that our data does not include other significant indicators such as time on site, unique users, or bounce rate. Our sample may also be missing some republishers that strip out the tracking pixel on their websites.

Between September 2017 and April 2019, articles had been published in 490 media outlets worldwide. For this study, we analyzed the top 50 republishers of The Conversation Canada from September 2017 to April 2019 in terms of reach using page views as a measure. This study focused on the top 50 republishers as they account for $74.8 \%$ of all the offsite page views for articles for the period June 2017-April 2019. The remaining 440 republishers account for the remainder of the $25.2 \%$ of page views. Publications ranked at 115 and below account for less than 10,000 page views each, those near the bottom in single digits. The figures point to a long tail for the reach of articles (Anderson, 2006).

The republishing data was coded according to publisher, topic focus on the publication, and geographical location. The top 50 republishers by page views were coded as legacy/professional journalism organizations, peripheral journalistic actors, and non-journalism organizations. The boundaries of the first category were set by considering how far the organizations were staffed by professional journalists who followed established professional norms and practices. Peripheral actors were defined as those that have not traditionally been considered as belonging to journalism practice. The third category included organizations not involved in journalism.

At a global level, the sample included The Washington Post, CNN, The Daily Mail and Quartz. At a national level, they include the National Post, Maclean's and Global News, while regional republishers include the Winnipeg Free Press and SooToday.com. At the niche level, they vary from sites focused on Canadian policy issues such as National Newswatch, to parenting publications such as Today's Parent, to science outlets such as IFLScience. The outlets were also analyzed by the nature of the publication, by topic, and by geographical location. Republishers were coded by the topic focus of the outlet to distinguish between general news and more specialist publications-general news, business, science, lifestyle, health, politics, arts and culture, weather, urban issues, and explicit point of view. The coding was undertaken by a research assistant and subsequently reviewed by the authors.

For a further layer of analysis, the data on the articles republished by The Weather Network (Canada) was also downloaded from The Conversation's analytics dashboard for the period June 24, 2017, to April 30, 2019. The data included the headline, author, and page views per article. The top 50 articles were coded for topic focus, such as climate change, natural disasters, policy issues, and animals. These included several related to climate change including pollution, habitat, sustainability, and resource development.

This article also draws on data on the scholarly contributors gathered through a survey of The Conversation Canada readers and authors in the spring of 2019. 1,342 registered contributors were emailed, encouraging them to take the survey. The survey was also promoted on the The Conversation Canada website, and on social media. Some 191 of the respondents identified themselves as contributors to the publication. The data was filtered by the number of contributors who said they had been contacted by another publication or media outlet (114 respondents) and by the type of media outlet/publication.

Additional data was obtained via The Conversation's proprietary analytics for the number of contributors and author pitches for the two years since launch to provide a further measure of uptake. The data includes the names of contributors, university affiliation, number of stories published, page views, and comments. The data on pitches includes the names of contributors, university affiliation, number of pitches, and topic. It only covers scholar pitches to the editorial team via the website. It does not include pitches by email to individual editors or by universities to editors on behalf of academics. We were particularly interested in examining the number of pitches as pitching a story to an editor is a fundamental journalism skill, requiring "precision in identifying the essential from inessential, the ability to synthesize and to systematize information and the confidence to present it" (de Burgh, 2003, p. 100). With the growth of philanthropic and crowdfunded journalism, there is more of a direct connection between funding and pitches (Aitamurto, 2011). Pitching is also considered an essential skill for PR professionals who will suggest a story idea to a journalist in an attempt to persuade them it is relevant and of interest to their audience, thus shaping what issues are covered (Jackson \& Moloney, 2016).

\section{Findings}

\subsection{Production: Scholars as Journalists}

As of June 2019, after 24 months in operation, 1,558 scholars and academics had written at least one article on The Conversation Canada, with a total of 1,937 articles published over the two years, some with more than one author. The majority of scholar contributors wrote one article, making up 1,150 (73.8\%) of the con- 
tributors. Another 235 scholars, (15\%), contributed two articles over the two-year period. Some 77 (4.9\%) contributed three articles and 37 (2.4\%) wrote four. A small number, 59 scholars, (3.8\%) wrote five or more articles. The top three most prolific contributors were: Michael J. Armstrong, Associate Professor of Operations Research at the Goodman School of Business, Brock University in Ontario, with 36 articles; Sylvain Charlebois, Director of the Agri-Food Analytics Lab and Professor in Food Distribution and Policy at Dalhousie University in Nova Scotia, with 31 articles; and Joel Lexchin, Professor Emeritus of Health Policy and Management, at York University, and Associate Professor of Family and Community Medicine, University of Toronto, with 15 articles. The figures suggest that the majority of scholars take on the role of journalist as a one-off action, rather than as a consistent activity of moving from the periphery to the core of journalistic production, when measured in terms of articles written for The Conversation Canada.

In addition, there are some indications of growing acceptance of The Conversation Canada from the wider field of journalism as being published is raising the prominence of scholar-journalists through exposure in the broader media. Our survey of authors found that $59.7 \%-114$ out of the 191 respondents who identified as contributors-said they had received requests to write or be interviewed by another publication or media outlet. The results are consistent with data from the longest-running Conversation site in Australia, launched in 2011, which found that $66 \%$ of Australian authors were contacted by other media after publication (The Conversation Media Group, 2017). In terms of media interest, the largest number of requests came from radio and newspapers (23.2\%). Self-reported data from academic contributors suggests a significant interest from the public service broadcaster, the Canadian Broadcasting Corporation. The next two highest numbers of requests came from online media (18.5\%) and from international media (11.4\%) such as the BBC (UK), NPR (US) and ABC (Australia). Television, magazines, and podcasts made up the rest.

On top of acceptance from traditional journalism organizations, the first two years of operation of The Conversation Canada indicate a steady increase in pitches submitted by academics via the website. There were 1,370 pitches between June 25, 2017, and June 30, 2019. In order to obtain a sense of the pace of pitches, the data was broken down into six-month periods. For just over the first six months of operation, from June 25 to December 31, 2017, there were 171 pitches from scholars. The number increased to 296 in the following six months, from January 1 to June 30,2018, for a total of 467 in the first year of operations. The number of pitches rose to 399 for the six months of July 1 to December 31, 2018. There was another rise to 571 in the six months January 1 to June 30, 2019, for a total of 970 in the second year of operations. The data shows how the pace of pitches has quickened, with the number more than doubling year on year.

\subsection{Publication: Organizational Structure}

The Conversation Canada is a registered not-for-profit society funded largely by a university membership model that explicitly states it is editorially independent of the university sector. The model is based on the mediatization of academic knowledge work, with the university sector as the newsroom (Rowe, 2017). It could be considered as a form of what Hepp and Loosen $(2019$, p. 2) have defined as "a particular group of professionals who incorporate new organizational forms and experimental practice in pursuit of redefining the field and its structural foundations." They use the term 'pioneer journalism' to describe journalism practices that involve "efforts to shift the field's organizational foundations" (Hepp \& Loosen, 2019, p. 2). In this sense, The Conversation model could be seen as reconfiguring the nature of what is considered a journalism organization. The model has been discussed by Pooley (2017) as the leading example of a new category of media, the impact platform, defined as "researcher-authored, professionally edited, openly licensed, and republication-friendly."

The Conversation model has faced critique and questions by some prominent journalists and journalism educators in Canada over whether it aligns within a traditional definition of journalism. These concerns stem partially from the funding model, with questions over editorial independence and whether the publishing model is different from established university communications. The main federal journalism think tank doing research on digital journalism and policy, the Public Policy Forum, included The Conversation in a major report for the federal government on the state of the media in Canada in a section labelled "Citizen Journalism." The report went on to note that "the Internet has thrown up a so-called 'second layer of vibrancy' by giving individuals a public voice on blogs, specialized sites, social media-based community billboards and academic sites such as opencanada.org and The Conversation" (Public Policy Forum, 2017, p. 76). That it framed The Conversation Canada as citizen journalism and not among an increasing number of digitalborn news organizations suggests it was seen in 2017 as one of Ahva's 'inbetweeners,' and part of a growing journalism periphery in Canada. In addition, most of the media coverage of The Conversation Canada's launch in 2017 was in higher education outlets and by university members themselves. One exception was a largely positive article in the Toronto Star ahead of launch (Wallace, 2017), published as part of a series on the state of the news and information landscape in Canada.

\subsection{Dissemination: Republishers}

Our analysis of the top 50 republishers in terms of reach found articles from The Conversation Canada were pre- 
dominantly republished by what would be considered professional news publications. Of the top 50 republishers, 33 (66\%) were categorized as professional journalism, 15 (30\%) were peripheral journalistic organizations, and two were non-journalism organizations. The professional journalism organizations include Maclean's magazine, The Daily Mail, Global News (Canada), and Salon. Peripheral republishers include Sci Fi Generation, Alternet, and The Weather Network (Canada). The two non-journalism actors (4\%) were University of Toronto News and the World Economic Forum.

Geographically, the largest number of republishers, 20 out of 50, were from the US. Perhaps this is unsurprising given the population size of 327 million in the US compared to 37 million in Canada. Canadian media accounted for 12 of the sample, with the UK third at nine. The rest were made up by Australia, India, New Zealand, South Africa, Southeast Asia, Spain, and Switzerland. The geographical spread can also be explained by the network with The Conversation affiliates in Australia, the UK, and the US.

The most common type of republisher was the general interest journalism publication, which accounted for $42 \%$ of the sample. All 21 of them were professional journalism publications. The second-largest contingent included 19 specialist publications (38\%), with 11 being peripheral actors. News, commentary, and analysis outlets account for $12 \%$, evenly split between mainstream and peripheral outlets. There was one legacy hyper-local outlet and one international non-journalism organization.

In terms of topic, more than half of the republishers provided general news. Of these, 25 were legacy outlets and two were peripheral actors-the aggregator Flipboard and Qrius, a news and analysis site based in India. The second highest topic was science, accounting for just under $10 \%$ of media. More significantly, two thirds of these republishers focused on science were peripheral actors such as Sci Fi Generation, IFLScience, and Phys.org. Among the other results were $8 \%$ of publications focused on business, with three legacy actors and one non-journalism. Another $8 \%$ were publications with an explicit point of view, made up mostly by peripheral actors such as Alternet and The Raw Story. Health only made up $4 \%$ while arts and culture, lifestyle, and weather were each at one publication (2\%).

An analysis of the data by the number of page views surfaced the significant reach of peripheral actors even though they only made up a third of the sample. In terms of audience, legacy media accounted for $51 \%$ of page views compared to $45 \%$ for peripheral actors and $4 \%$ for non-journalism outlets. The largest republisher in terms of reach was The Weather Network (Canada), which would not be considered a legacy or elite news organization. It accounted for $9 \%$ of all page views. Second was the news aggregator, Flipboard, which accounted for $7.3 \%$ of page views. The highest mainstream republisher was Maclean's magazine, which made up $4.7 \%$ of page views. For comparison, The Weather Network (Canada) published 133 articles from The Conversation Canada. Flipboard published some 1,614 articles and Maclean's published 116.

An analysis of the content published by The Weather Network (Canada) shows a focus on substantive issues. There are some articles on popular topics such as bed bugs and crop circles. But almost half of the pieces republished focused on climate change, sustainability, resource development, and pollution. These include articles from the future of the Arctic to the impact of road salt on the environment to the potential benefits of green roofs. The analysis and commentary on environmental issues suggests that, as a peripheral actor, The Weather Network (Canada) could be addressing an information need left by the mainstream media (Schäfer, 2015) on arguably some of the most pressing and important national and global concerns.

\section{Discussion and Conclusion}

Our research is intended as an exploratory study that contributes to the emerging body of literature on peripheral actors, addressing the call by Grafström and Windell "that future research should continue to explore when and how novel actors are incorporated into organizational fields, and under what circumstances they have less or greater possibilities to alter established structures of domination" (2012, p. 75). Our findings point to early uptake of a complex peripheral actor initially identified as an 'inbetweener' in a field that is undergoing commercial market decline. A 2017 governmentinitiated and funded report described legacy media in Canada as "once indispensable agencies of information, the 20th-century news media are less and less prominent, except to provide grist for a public conversation they no longer control" (Public Policy Forum, 2017, p. 17). In a sign of the economic headwinds in the news media, the federal government has earmarked more than $\$ 600$ million to support journalism, largely through tax credits for journalism jobs and news subscriptions. It is also extending the definition of charitable status to include journalism organizations.

Our results point to an increasing uptake in the number of scholars contributing as peripheral actors to The Conversation Canada. They also highlight more scholars seeking to write for the site, given the increase in the number of pitches submitted to the newsroom via the web. The findings show demand for content from The Conversation Canada from legacy journalism experiencing increasing market pressures in Canada and a growing number of peripheral journalism actors. It is both this institutional recognizability along with decline of legacy journalism actors-the largest legacy republisher has seen multiple layoffs over the past few years (Watson, 2017) - and rising numbers of digital niche peripheral actors that have contributed to its growth. Perhaps one of the most powerful indicators of its shifting status as a journalism producer is the 2018 Public Policy Forum re- 
port, which upgraded The Conversation Canada from citizen journalism inbetweener to playing a role "in strengthening journalism and local news" (Public Policy Forum, 2018, p. 19) and the entire "media system" (Public Policy Forum, 2018, p. 12) in the course of a year.

The backdrop is a media landscape in Canada that is dominated by a handful of legacy commercial and public broadcasting journalism actors, such as the CBC, The Globe and Mail, The Toronto Star, Postmedia, CTV News, and Global News, which continue to enjoy significant reach (Newman, Fletcher, Kalogeropoulos, \& Nielsen, 2019). Of these, Global News, the Postmedia network, and The Toronto Star have taken articles from The Conversation Canada. We find this gap worthy of further exploration. Out of the 12 Canadian republishers in terms of reach, 10 were legacy players. The Weather Network (Canada) was the only peripheral journalism player and one was a non-journalism outlet, the University of Toronto. The prominence of The Weather Network (Canada) as the largest single republisher in terms of audience reach signals how the field of journalism is encompassing novel actors. In 2004, Zelizer talked about the Weather Channel in the U.S. as not being considered journalism despite its popularity, and the fact that it has consistently been a feature in news output, particularly in weather forecasts on television and radio (Henson, 2010; Zelizer, 2004). She links it to other peripheral actors at the time:

Consider a repertoire of candidates that would not currently merit membership under the narrowed definition of journalism: A Current Affair, MTV's The Week in Rock, internet listservs, Jon Stewart, www.nakednews.com, reporters for the Weather Channel...are but a few that come to mind. (Zelizer, 2004, p. 6)

Zelizer's opinion was however contested among contemporary scholarship such that the cable channel prompted observations that it "seemed more like news than 'weather' in the traditional sense" (Seabrook, 2000). Weather reporting has also evolved with the advent of digital media, so that "news stories about the weather have gained a prominence in online media that they never attained in print" (Zion, 2019, p. 3). This prominence is reflected in organizational growth with the Weather Channel in the U.S. expanding its digital newsroom from 10 in 2012 to more than 60 by 2018, becoming "a destination for narrative storytelling and investigative reporting on everything from climate change to toxic algae to immigration" (Willyard, 2018).

The number and reach of peripheral actors such as The Weather Network (Canada) in this case study indicate how novel actors can gain an increasingly central role in stimulating access to evidence-based explanatory journalism at a time of commercial journalism decline. Similar to studies of The Weather Channel, the material republished by The Weather Network (Canada) suggests that audiences are encountering research and analysis on a key policy issue without either intentionally seeking it out or trying to avoid it. They are an inadvertent audience who are exposed to news and information as a by-product of the medium, much as television during the 1960s and 1970s was seen as a way for audiences to "fall into the news" (Robinson, 1976, p. 426).

As a result, we argue that scholars need to take complex peripheral actors seriously as they appear to be growing in prominence and reach. Complex actors operate across multiple stages in the production, publication, and distribution/dissemination of news and information. For example, Google, Facebook, and Apple News could be considered complex peripheral actors given how they act as hosts for, and gateways to, news. Such complex peripheral actors are benefitting from a global platform technological environment, the proliferation of free content and increasingly multiple journalisms (Callison \& Young, in press; Papacharissi, 2015). The study contributes to the emerging literature on peripheral actors by going beyond individual and mostly human, actors, adding considerations of the organizational model and distribution/dissemination. Our results suggest a need to consider how different peripheral actors operate at different steps of the journalistic process to acknowledge the complex forces at work.

The case study of The Conversation Canada surfaces how it operates as a complex peripheral actor. It provides an analysis of the interactions of peripheral actors within one institution in a national journalism field, in this case a mature Western media system (Fletcher \& Nielsen, 2017) characterized largely by commercial media with a respected but comparatively underfunded public broadcaster. In today's high choice media environment with multiple actors-and concerns that "infinite choice equals ultimate fragmentation" (Anderson, 2006, p. 181)-some newer players are benefitting from this environment depending on the nature of their intervention and in this case, their recognition as journalism. Our findings are particularly interesting given that Canadian journalism organizations have traditionally been critiqued for a "pernicious ethnocentrism which fails to recognize, perhaps even denies, the cosmopolitan nature of the news audience and its place in a globalized and networked world" (Gasher, 2007, p. 316).

In closing, Eldridge has suggested that embracing newer journalism actors available via digital and social media risks diluting the "cultural and symbolic capital of being a journalist" (2017, p. 186). This approach however neglects the existence of a global context of multiple journalisms and media systems that are increasingly in relationship to each other in a digital landscape, as well as the fact that definitions of journalism change over time and place. A key area for further research, then, is how to gauge who matters, as this has been traditionally based on circulation and audience numbers. The emergence of novel actors and studies of their contemporary trajectories do not merely prompt an examination of the 
changing media landscape. Rather, these new entrants contest an entrenched view among journalism studies scholars that the notion of a single journalism matters, and that it can be understood outside of its historical and systemic context.

\section{Acknowledgments}

This research was supported by the Social Sciences and Humanities Research Council of Canada. The authors would like to sincerely thank the reviewers and editors of the thematic issue for their insightful comments that have strengthened this paper.

\section{Conflict of Interests}

The authors declare no conflict of interests.

\section{References}

Ahva, L. (2017). How is participation practiced by "in-betweeners" of journalism? Journalism Practice, $11(2 / 3), 142-159$.

Aitamurto, T. (2011). The impact of crowd funding on journalism. Journalism Practice, 5(4), 429-445.

Anderson, C. (2006). The long tail: How endless choice is creating unlimited demand. London: Random House.

Baack, S. (2018). Practically engaged: The entanglements between data journalism and civic tech. Digital Journalism, 6(6), 673-692.

Belair-Gagnon, V., \& Holton, A. E. (2018). Boundary work, interloper media, and analytics in newsrooms: An analysis of the roles of web analytics companies in news production. Digital Journalism, 6(4), 492-508.

Bennett, W. L., Segerberg, A., \& Yang, Y. (2018). The strength of peripheral networks: Negotiating attention and meaning in complex media ecologies. Journal of Communication, 68(4), 659-684.

Benson, R. (2017). Can foundations solve the journalism crisis? Journalism, 19(8), 1059-1077.

Bourdieu, P. (1984). Distinction. Cambridge, MA: Harvard University Press.

Bruns, A. (2018). Gatewatching and news curation: Journalism, social media, and the public sphere. New York, NY: Peter Lang.

Callison, C., \& Hermida, A. (2015). Dissent and resonance: \#Idlenomore as an emergent middle ground. Canadian Journal of Communication, 40(4), 695-716.

Callison, C., \& Young, M. L. (in press). Reckoning: Journalism's limits and possibilities. New York, NY: Oxford University Press.

Carlson, M. (2016). Metajournalistic discourse and the meanings of journalism: Definitional control, boundary work, and legitimation. Communication Theory, 26(4), 349-368.

Cheruiyot, D., Baack, S., \& Ferrer-Conill, R. (2019). Data journalism beyond legacy media: The case of African and European civic technology organizations. Digital
Journalism. Advance online publication. https://doi. org/10.1080/21670811.2019.1591166

Davey, K. (1970). The uncertain mirror: Report of the Special Senate Committee on mass media. Ottawa: Queen's Printer.

de Burgh, H. (2003). Skills are not enough: The case of journalism as an academic discipline. Journalism, 4(1), 95-112.

DiMaggio, P. J., \& Powell, W. W. (1983). The iron cage revisited: Institutional isomorphism and collective rationality in organization fields. American Sociological Review, 48(2), 147-160.

Distil Networks. (2019). 2019 bad bot report. San Francisco, CA: Distil Networks. Retrieved from https://resources.distilnetworks.com/white-paperreports/bad-bot-report-2019

Donsbach, W. (2010). Journalists and their professional identities. In S. Allan (Ed.), The Routledge companion to news and journalism (pp. 38-59). Abingdon: Routledge.

Eldridge, S. A., II. (2017). Online journalism from the periphery: Interloper media and the journalistic field. Abingdon: Routledge.

Fletcher, R., \& Nielsen, R. K. (2017). Are news audiences increasingly fragmented? A cross-national comparative analysis of cross-platform news audience fragmentation and duplication. Journal of Communication, 67(4), 476-498.

Gasher, M. (2007). The view from here. Journalism Studies, 8(2), 299-319.

Grafström, M., \& Windell, K. (2012). Newcomers conserving the old: Transformation processes in the field of news journalism. Scandinavian Journal of Management, 28(1), 65-76.

Groves, J., \& Brown, C. L. (2011). Stopping the presses: A longitudinal case study of the Christian Science Monitor transition from print daily to web always. \#ISOJ: The Official Research Journal of the International Symposium on Online Journalism, 1(2) 95-134.

Henson, R. (2010). Weather on the air: A history of broadcast meteorology. Boston, MA: American Meteorological Society.

Hepp, A., \& Loosen, W. (2019). Pioneer journalism: Conceptualizing the role of pioneer journalists and pioneer communities in the organizational re-figuration of journalism. Journalism. Advance online publication. https://doi.org/10.1177/1464884919829277

Hermida, A. (2016). Social media and the news. In T. Witschge, C. W. Anderson, D. Domingo, \& A. Hermida (Eds.), The Sage handbook of digital journalism (pp. 81-94). London: Sage.

Hermida, A., \& Young, M. L. (2019). Data journalism and the regeneration of news. Abingdon: Routledge.

Holton, A. E., \& Belair-Gagnon, V. (2018). Strangers to the game? Interlopers, intralopers, and shifting news production. Media and Communication, 6(4), 70-78.

lacono, J., Brown, A., \& Holtham, C. (2009). Research methods: A case example of participant observa- 
tion. Electronic Journal of Business Research Methods, 7(1), 39-46.

Jackson, D., \& Moloney, K. (2016). Inside churnalism: PR, journalism, and power relationships in flux. Journalism Studies, 17(6), 763-780.

Kent, T. (1981). Royal commission on newspapers. Ottawa: Privy Council Office. Retrieved from http:// publications.gc.ca/site/eng/472245/publication.html

Konieczna, M. (2018). Journalism without profit: Making news when the market fails. Oxford: Oxford University Press.

Krall, J. (2009). Using social metrics to evaluate the impact of online healthcare communications. Journal of Communication in Healthcare, 2(4), 387-394.

Leblebici, H., Salancik, G. R., Copay, A., \& King, T. (1991). Institutional change and the transformation of interorganizational fields: An organizational history of the U.S. radio broadcasting industry. Administrative Science Quarterly, 36(3), 333-363.

Lewis, S. C. (2012). The tension between professional control and open participation. Information, Communication \& Society, 15(6), 836-866.

Lowrey, W. (2006). Mapping the journalism-blogging relationship. Journalism, 7(4), 477-500.

Meraz, S., \& Papacharissi, Z. (2016). Networked framing and gatekeeping. In T. Witschge, C. W. Anderson, D. Domingo, \& A. Hermida (Eds.), The Sage handbook of digital journalism (pp. 95-112). London: Sage.

Newman, N., Fletcher, R., Kalogeropoulos, A., Levy, D., \& Nielsen, R. K. (2017). Reuters Institute digital news report 2017. Oxford: Reuters Institute for the Study of Journalism.

Newman, N., Fletcher, R., Kalogeropoulos, A., \& Nielsen, R. K. (2019). Reuters Institute digital news report 2019. Oxford: Reuters Institute for the Study of Journalism. Retrieved from http://www. digitalnewsreport.org/survey/2019/canada-2019

Nielsen, R. K. (2012). How newspapers began to blog. Information, Communication \& Society, 15(6), 959-978.

Papacharissi, Z. (2015). Toward new journalism(s). Journalism Studies, 16(1), 27-40.

Pooley, J. (2017). The impact platform. Social Science Research Council. Retrieved from https://items.ssrc. org/parameters/the-impact-platform

Public Policy Forum. (2017). The shattered mirror: News, democracy and trust in the digital age. Ottawa: Public Policy Forum.

Public Policy Forum. (2018). What the Saskatchewan roughriders can teach Canadian journalism. Ottawa: Public Policy Forum. Retrieved from https:// ppforum.ca/wp-content/uploads/2018/09/What TheSaskatchewanRoughridersCanTeachCanadian Journalism-PPF-SEPT2018.pdf

Robinson, M. J. (1976). Public affairs television and the growth of political malaise: The case of "The selling of the Pentagon." American Political Science Review, 70(2), 409-432.
Rowe, D. (2017). The university as a 'giant newsroom': The uses of academic knowledge revisited. Culture Unbound, 9(3), 228-239.

Schäfer, M. S. (2015). Climate change and the media. In J. Wright (Ed.), International encyclopedia of the social \& behavioral sciences ( 2 nd ed., pp. 853-859). Amsterdam: Elsevier.

Schneiberg, M. (2007). What's on the path? Path dependency, organizational form and the problem of institutional change in the US economy, 1900-1950. Socio-Economic Review, 5(1), 47-80.

Scott, M., Bunce, M., \& Wright, K. (2019). Foundation funding and the boundaries of journalism. Journalism Studies, 20(14), 2034-2052.

Seabrook, J. (2000, April 3). Selling the weather: The climate is becoming more extreme and so is the way we watch it. The New Yorker. Retrieved from http:// www.johnseabrook.com/selling-the-weather

Siles, I., \& Boczkowski, P. J. (2012). Making sense of the newspaper crisis: A critical assessment of existing research and an agenda for future work. New Media \& Society, 14(8), 1375-1394.

Singer, J. B. (2003). Who are these guys? The online challenge to the notion of journalistic professionalism. Journalism, 4(2), 139-163.

Singer, J. B., Hermida, A., Domingo, D., Heinonen, A., Paulussen, S., Quandt, T., \& . . Vujnovic, M. (2011). Participatory journalism: Guarding open gates at online newspapers. Malden, MA: John Wiley \& Sons.

Tandoc, E. C., Jr., \& Oh, S. K. (2017). Small departures, big continuities? Journalism Studies, 18(8), 997-1015.

The Conversation Media Group. (2017). 2017 annual stakeholder report. Melbourne: The Conversation. Retrieved from https://cdn.theconversation.com/ static_files/files/14/2017_Stakeholder_Report_ The_Conversation.pdf

Usher, N. (2012). Going web-first at the Christian Science Monitor: A three-part study of change. International Journal of Communication, 6(June), 1898-1917.

Wallace, C. (2017, May 21). Academics and journalists are in on The Conversation. Toronto Star. Retrieved from https://www.thestar.com/news/atkinson series/newnewsroom/2017/05/21/academics-andjournalists-are-in-on-the-conversation.html

Watson, H. G. (2017, February 1). Maclean's hit by layoffs. J-Source. Retrieved from https://j-source.ca/article/ macleans-hit-by-layoffs

Willyard, C. (2018, March 2). How The Weather Channel became an investigative powerhouse. Columbia Journalism Review. Retrieved from https://www.cjr.org/ united_states_project/the-weather-channel.php

Winseck, D. (2018). Media and internet concentration in Canada, 1984-2017. Ottawa: Canadian Media Concentration Research Project. Retrieved from http://www.cmcrp.org/media-and-internetconcentration-in-canada-1984-2017-updated

Zelizer, B. (2004). Taking journalism seriously: News and the academy. Thousand Oaks, CA: Sage. 
Zion, L. (2019). Weather coverage. In T. P. Vos, F. Hanusch, D. Dimitrakopoulou, M. Geertsema-Sligh, \&
A. Sehl (Eds.), The international encyclopedia of journalism studies (pp. 1-8). Chicester: Wiley.

\section{About the Authors}

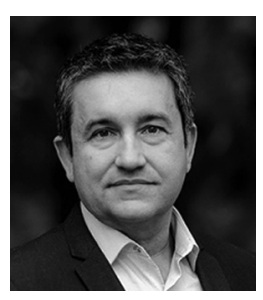

Alfred Hermida (PhD) is Associate Professor and Director of the School of Journalism at the University of British Columbia, and Co-Founder and Board Member of The Conversation Canada. He does not own shares in or receive funding from The Conversation Canada. With more than two decades of experience in digital journalism, his research explores the transformation of media, emerging news practices, innovation, and social media. His most recent book, co-authored with Mary Lynn Young, is Data Journalism and the Regeneration of News (Routledge, 2019). He was a BBC journalist for 16 years.

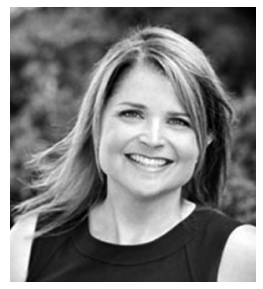

Mary Lynn Young (PhD) is an Associate Professor, Co-Founder and Board Member of The Conversation Canada. She does not own shares in or receive funding from The Conversation Canada. She has held a number of academic administrative positions at UBC, including director of the UBC School of Journalism (2008-2011). She has two recent co-authored books: Reckoning: Journalism's Limits and Possibilities (Oxford, 2020), with Candis Callison; and Data Journalism and the Regeneration of News (Routledge, 2019), with Alfred Hermida. 